\title{
Incidence of Microorganisms of Hygienic Interest in Organized and Unorganized Abattoirs of Jammu Region, India
}

\author{
Nishchal Dutta $^{1 *}$, Shafiqur Rahman ${ }^{2}$, Ishfaq Maqbool ${ }^{3}$ and Najeeb ul Tarfain ${ }^{4}$
}

${ }^{1}$ Department of Veterinary Pathology, ${ }^{3}$ Department of Veterinary Parasitology, ${ }^{4}$ Department of Veterinary Microbiology, College of Veterinary Science Guru Angad Dev Veterinary and Animal Sciences University, Ludhiana-141004, Punjab, India

${ }^{2}$ Division of Veterinary Pathology, Sher-i-Kashmir University of Agricultural Sciences and Technology, R S Pura-181102, Jammu, India

*Corresponding author

\section{A B S T R A C T}

Magnitude of illness due to meat consumption is unknown due to lack of surveillance networks. Monitoring the food borne pathogens and indicators of contamination in primary production at abattoirs is imperative for creating data bank and for effective control of such pathogens before they enter the food chain. Micro-organisms of hygienic interest in respiratory tract were screened for incidence at organized and un-organized abattoirs of Jammu region. The suspected samples were collected from nasal cavity, trachea and lungs by use of cotton swabs kept in transport media. A total of 330 samples were collected and analyzed for Streptococcus spp., Staphylococcus spp., Pasteurella spp., Pseudomonas spp. and E. coli. Apparently healthy animals and diseased animals showed incidence of microbes as $45.59 \%$ and $86.86 \%$ respectively. Nasal swab, tracheal samples and lung samples respectively showed incidence of $69.72 \%, 65.18 \%$ and $50.00 \%$ respectively. Staphylococcus spp. showed highest percentage $(35.26 \%)$ while E. coli was represented the lowest (3.76\%). Streptococcus, Pasteurella and Pseudomonas respectively, represented $23.67 \%, 22.70 \%$ and $11.11 \%$.

\section{Introduction}

Food borne diseases are threat to public health worldwide. The repercussions are not only health related but also have economic ramifications from the loss of business over food safety issues. Sophisticated mechanisms are available in developed countries for timely identification and spreading of zoonotic diseases of food origin. However, in developing countries related data is not available because of lack of precise health care infrastructure and data management (Bhandare et al., 2010). About 1.8 million children in developing countries succumb to death from acute microbial diseases with food or water being the major causes of many of these illnesses (World Health Organization, 2000). Emerging/ re-emerging zoonotic food borne and water borne diseases as well as 
diseases caused by multi-resistance organisms are the major public health threats in India (Chugh, 2008). However, the magnitude of food borne illness in India is unknown due to the lack of coordinated surveillance network.

Jammu and Kashmir needs special mention since the meat consumption in this state is high and meat is obtained from organized, unorganized and retail shops. Hardly any emphasis is being laid on hygienic meat practices and the consumers are forced to consume potential threatening microorganisms along with meat. Monitoring the incidence and prevalence of micro-organisms of hygienic interest in primary production at abattoirs is imperative for creating data bank and for effective control of such pathogens before they enter the food chain. Therefore present study was undertaken at organized and unorganized to determine incidence of microorganisms of hygienic importance.

\section{Materials and Methods}

The study was conducted on sheep, both apparently healthy and diseased, that were slaughtered routinely as a source of food in neighbouring areas of the Jammu division from organized and unorganized abattoirs of Gujjar Nagar, Dogra hall, Bishnah and Nagrota. The suspected samples were collected from nasal cavity, trachea and lungs by use of cotton swabs kept in transport media. A total of 330 samples from July 2012 to June 2013 were collected. Sterile cotton swabs $(3 \mathrm{~cm}$ long and $1 \mathrm{~cm}$ in diameter) held by wooden sticks and moistened by with 0.1 $\%$ peptone were rubbed on the sites for 30 seconds and transferred to a screw capped test tube containing $10 \mathrm{ml}$ of sterile maintenance medium $(0.85 \% \mathrm{NaCl}$ and $0.1 \%$ peptone). The screw capped test tubes were brought to laboratory in thermos flask containing ice and processed immediately.
The procedure for isolation and identification of bacterial culture adopted for the present work was as per Holt (Holt, 1994). The samples collected from different areas were inoculated in blood agar, nutrient agar and MacConkey's agar and incubated at $37^{\circ} \mathrm{C}$. After 24 hours of incubation, the colonies were purified and stained with Gram stain for microscopic examination as described by Beveridge (Biveridge, 2001). Respective cultures were identified on the basis of standard criteria and biochemical tests (Quinn et al., 1998). Suspected growing colonies onto the surface of the above mentioned media were characterized on the basis of their colonial morphology and staining reactions. One single colony showed typical colonial appearance and morphological character was picked up, streaked into semisolid agar media, and incubated at $37^{\circ} \mathrm{C}$ for 24 hours for further identification (Cruickshank et al., 1995).

\section{Results and Discussion}

Results obtained revealed that out of 193 apparently healthy sheep, 88 were positive for bacteriological infection with an incidence of $45.59 \%$ and as for diseased animals, 119 out of 137 sheep were positive with an incidence of $86.86 \%$ (Table 1 ).

A total of 207 positive samples were isolated from 330 specimens with an incidence of $62.72 \%$. From 193 apparently healthy animals, 88 were positive with an incidence of $45.59 \%$ and in 137 diseased animals, 119 were positive with an incidence of $86.86 \%$. In diseased sheep, swabs taken from nasal mucosa showed the higher incidence (38 isolates out of 42 swabs) with an incidence $90.47 \%$, while the lowest incidence rate observed in samples taken from lungs (29 isolates out of 37 samples) with an incidence of $78.37 \%$. In apparently healthy sheep, the incidence rate followed the same trend as that observed in diseased sheep (Table 2). 
Identified bacteria were Gram positive Streptococcus spp., Staphylococcus spp. and Gram negative Pasteurella spp., Pseudomonas and E. coli (Plate 1, 2, 3, 4, 5) (Fig. 1 and 2) and their incidence is summarised in table 3. Staphylococci were found to be the predominant bacteria isolated with an incidence of $35.26 \%$. Second and third position was occupied by Streptococcus spp. and Pasteurella spp. with incidence rate of $23.67 \%$ and $22.70 \%$ respectively. The incidence of $E$. coli was lowest at $3.76 \%$. The present data represents the incidence of a diversity of microflora in the healthy and diseased sheep respiratory tract/carcases. The data collected from government organised and local abattoir showed bacteria (Streptococcus spp., Staphylococcus spp., Pasteurella spp., Pseudomonas spp. and E. coli) were involved in causing respiratory affections.

Table.1 Incidence of bacterial infection (\%) from apparently healthy and diseased animals $(n=330)$

\begin{tabular}{|c|c|c|c|c|c|c|c|}
\hline \multirow[t]{2}{*}{ Animal } & \multicolumn{4}{|c|}{ Apparently healthy animals } & \multicolumn{3}{|c|}{ Diseased animals } \\
\hline & $\begin{array}{l}\text { No. of } \\
\text { animals }\end{array}$ & examined & $\begin{array}{l}\text { No. of } \\
\text { positive } \\
\text { animals }\end{array}$ & $\%$ & $\begin{array}{l}\text { No. of } \\
\text { examined } \\
\text { animals }\end{array}$ & $\begin{array}{l}\text { No. of } \\
\text { positive } \\
\text { animals }\end{array}$ & $\%$ \\
\hline Sheep & 193 & & 88 & 45.59 & 137 & 119 & 86.86 \\
\hline
\end{tabular}

Table.2 Total recovery rate (\%) of bacterial microorganisms from apparently healthy and diseased sheep $(n=330)$

\begin{tabular}{|c|c|c|c|c|c|c|c|c|c|}
\hline \multirow[t]{2}{*}{ Sites } & \multicolumn{3}{|c|}{ Apparently healthy animals } & \multicolumn{3}{|c|}{ Diseased animals } & \multicolumn{3}{|c|}{ Total } \\
\hline & $\begin{array}{c}\text { No. of } \\
\text { examined } \\
\text { samples }\end{array}$ & $\begin{array}{l}\text { No. of } \\
\text { positive } \\
\text { samples }\end{array}$ & $\begin{array}{c}\% \\
\text { positive }\end{array}$ & $\begin{array}{c}\text { No. of } \\
\text { examined } \\
\text { samples }\end{array}$ & $\begin{array}{l}\text { No. of } \\
\text { positive } \\
\text { samples }\end{array}$ & $\begin{array}{c}\% \\
\text { positive }\end{array}$ & $\begin{array}{c}\text { No. of } \\
\text { examined } \\
\text { samples }\end{array}$ & $\begin{array}{l}\text { No. of } \\
\text { positive } \\
\text { samples }\end{array}$ & $\begin{array}{c}\% \\
\text { positive }\end{array}$ \\
\hline $\begin{array}{l}\text { Nasal } \\
\text { swab }\end{array}$ & 67 & 38 & 56.71 & 42 & 38 & 90.47 & 109 & 76 & 69.72 \\
\hline $\begin{array}{l}\text { Tracheal } \\
\text { samples }\end{array}$ & 77 & 36 & 46.75 & 58 & 52 & 89.65 & 135 & 88 & 65.18 \\
\hline $\begin{array}{l}\text { Lung } \\
\text { samples }\end{array}$ & 49 & 14 & 28.57 & 37 & 29 & 78.37 & 86 & 43 & 50.00 \\
\hline Total & 193 & 88 & 45.59 & 137 & 119 & 86.86 & 330 & 207 & 62.72 \\
\hline
\end{tabular}

Table.3 Identification of bacteria (\%) from sheep $(\mathrm{n}=330)$

\begin{tabular}{|l|c|c|}
\hline Identified bacteria & No. of positive samples & \% positive \\
\hline Streptococcus spp. & 49 & 23.67 \\
\hline Staphylococcus spp. & 73 & 35.26 \\
\hline Pasteurella spp. & 47 & 22.70 \\
\hline Pseudomonas spp. & 23 & 11.11 \\
\hline E.coli & 15 & 3.76 \\
\hline \hline Total & 207 & \\
\hline
\end{tabular}


Figure.1 (A)Streptococcus bacteria grown on sheep blood agar showing beta hemolysis; (B) Staphylococcus spp. grown on nutrient agar showing yellow colonies; (C) Pasteurella spp. grown on sheep blood agar showing beta haemolysis; (D) Pseudomonas spp. grown on nutrient agar showing bluish- green colonies; (E) E. coli grown on EMB agar showing characteristic metallic sheen
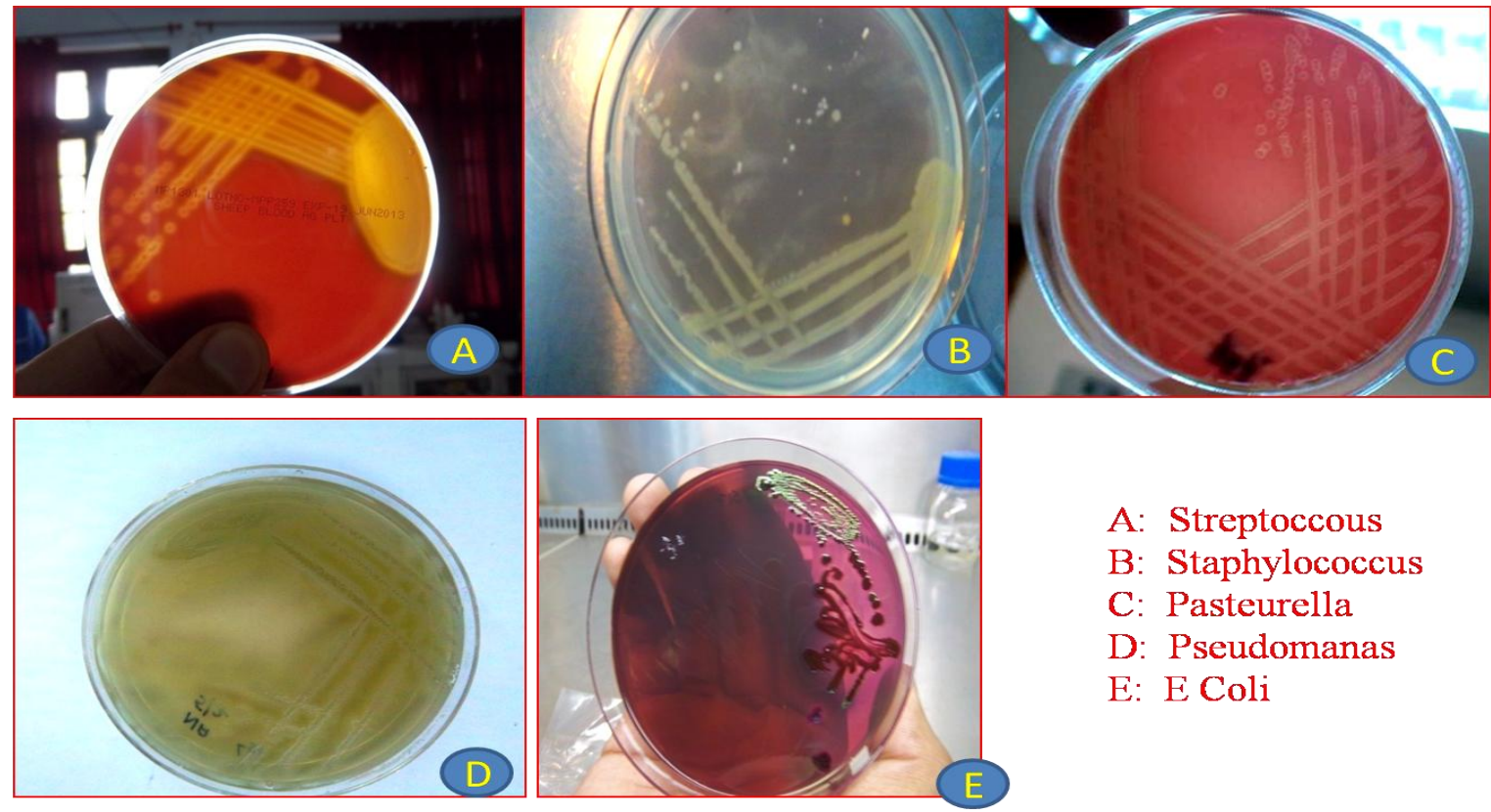
A: Streptoccous
B: Staphylococcus
C: Pasteurella
D: Pseudomanas
E: E Coli

Figure.2 (A) Long chain like colony of Streptococcus bacteria as seen under microscope;(B) Bunch of grapes like colony characteristic of Staphylococcus bacteria; (C) Pasteurella spp. showing characteristic bipolar staining.; (D) Gram -ve rods (Pseudomonas spp.)as seen under microscope; (E) Gram -ve rods (E.coli)as seen under microscope (100X)
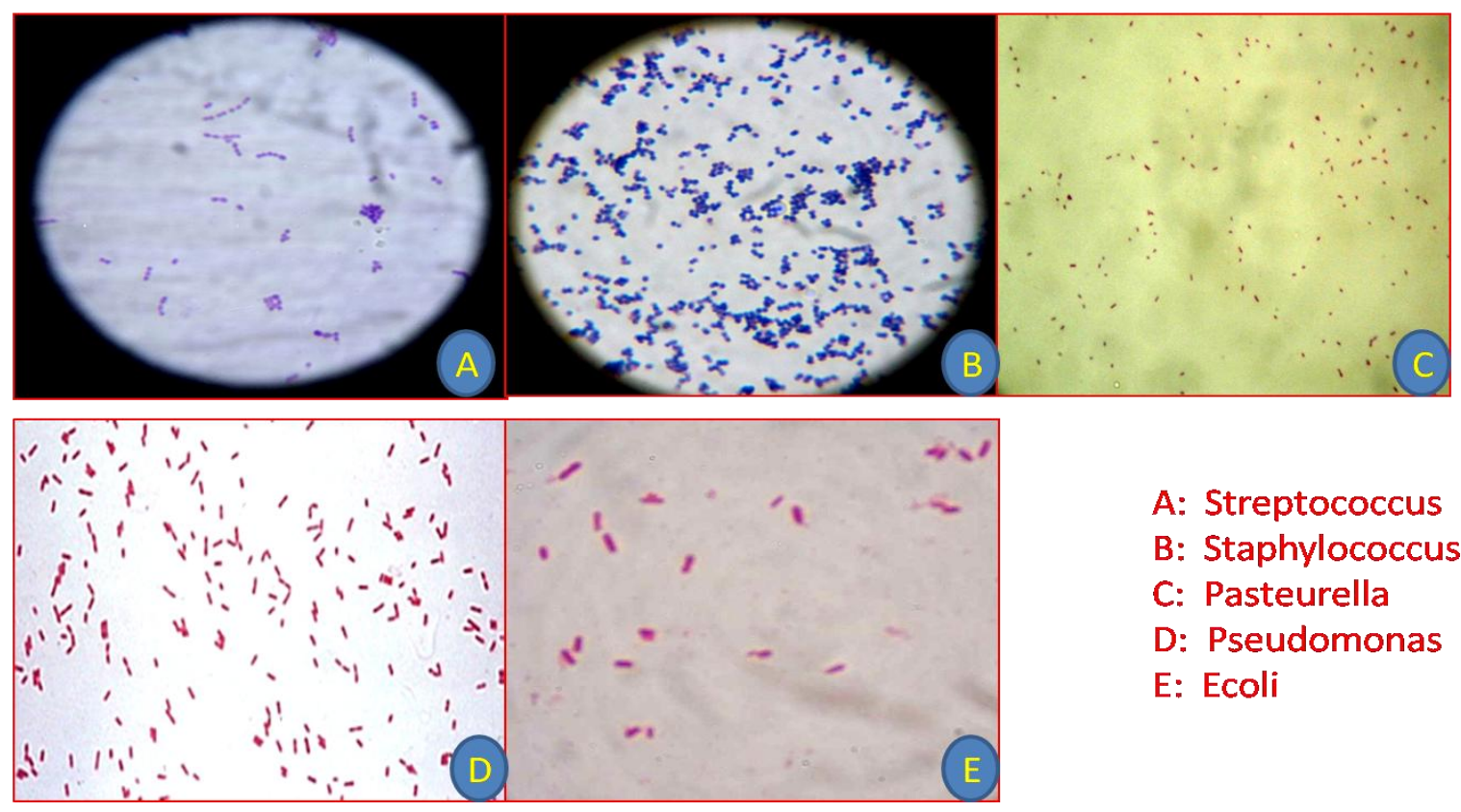
A: Streptococcus
B: Staphylococcus
C: Pasteurella
D: Pseudomonas
E: Ecoli 
The findings are in agreement with the findings of Azizi et al., (2013) who found incidence of Pasteurella spp. to be 24.53\%.Low percentage of Pasteurella, however, was reported by Raji et al., (2000). Ugochukwu (1985) found the prevalence of Staphylococci to be (33.33\%) which is near to results obtained in present study $(35.26 \%)$. Azizi et al., (2013) and Momin et al., (2011) reported lower value as $20.75 \%$ and $24 \%$ respectively in slaughtered sheep. Yesuf et al., (2012) found the prevalence of Streptococci spp. to be $13.79 \%$.Similarly, in another study by Aden et al., (2012) prevalence of E. coli infection was $14.3 \%$ which is higher than the value of present study. Emikpe et al., (2009) in a study found prevalence of Pseudomonas spp. infection to be $5.5 \%$ which coincides with the present study. Özbey (2004) too recorded lower percentage of isolation of Pseudomonas spp with total percentage of its isolation as $5.85 \%$.

In the present study the highest incidence was of Staphylococci bacteria while the least bacteria identified were E. coli. This finding is due to the staphylococci being the normal commensals of the respiratory tract while $E$. coli being the abnormal residents of the respiratory tract. To evaluate the effectiveness food safety programmes base line studies are needed to determine the levels of indicator organisms and prevalence of pathogens (Boyachuk et al., 2009).

The data demonstrates high prevalence and diversity of micro flora on carcasses in the primary Indian Production facility which might be due to lack of application of proper ante mortem and post mortem procedures in slaughter houses.

\section{Acknowledgements}

The authors are highly thankful to the Dean, Faculty of Veterinary Sciences, R.S Pura,
Jammu for granting permission and facilities to conduct this research work.

\section{References}

Aden, O., Ayalew, B., Mersha, C., and Tewodros, F. 2012. Isolation and identification of aerobic bacterial flora in Nasopharyngeal passage ways of apparently healthy and clinically sick sheep at Gondar University Veterinary Clinic. American-Eurasian J. Sci. Res., 7(6): 232-237.

Azizi, S., Korani, F. S., and Oryan, A. 2013. Pneumonia in slaughtered sheep in south-western Iran: pathological characteristics and aerobic bacterial aetiology. Veterinaria Italiana., 49(1): 109-118.

Beveridge, T. J. 2001. Use of the Gram stain in microbiology. Biotechnic. Histochemi., 76(3): 111-118

Bhandare, S. G., Paturkar, A. M., Waskar, V. S., and Zende, R. J. 2010.Prevalence of microorganisms of hygienic interest in an organized abattoir in Mumbai, India. J. Infect. Dev. Ctries., 4(07): 454-458.

Bohaychuk, V. M., Checkley, S. L., Gensler, G. E., and Barrios, P. R. 2009. Microbiological baseline study of poultry slaughtered in provincially inspected abattoirs in Alberta, Canada. Canadian Vet. J., 50(2): 173-178.

Chugh, T. D. 2008. Emerging and reemerging bacterial diseases in India.J. Bio. Sci., 33(4): 549-555.

Cruickshank, R., Duguid, J. P., Marmion, B. P., and Swain, R. H. A. 1973. Medical Microbiology, the Practice of Medical Microbiology. (12 $2^{\text {th }}$ Ed.). Vol. 11, Churchill Livingstone Limited, Edinburgh, London and New York. Pp. 195.

Emikpe, B. O., Oyero, O. G., and Akpavie, S. O. 2009. Isolation and antibiogram of aerobic nasal bacterial flora of apparently healthy West African dwarf 
goats. Revued'elevage et de medicine veterinaire des pays tropicaux., 62(1): 17-21.

Holt, J. G., Krieg, N. R., Sneath, P. A., Staley, J. T., and Williams, S. T. 1994. Bergey's Manual of determinate bacteriology $\left(9^{\text {th }}\right.$ Ed.). Springer, Boston, MA.

Momin, M. A., Islam, M. A., Khatun, M. M., and Rahman, M. M. 2012. Characterization of bacteria associated with pneumonia in Black Bengal goats. Bangladesh J. Vet. Med., 9(1): 67-71.

Özbey, G., and Muz, A. 2004. Isolation of aerobic bacterial agents from the lungs of sheep and goats with pneumonia and detection of Pasteurella multocida and Mannheimia haemolytica by polymerase chain reaction. Turkish J. Vet. Anim. Sci., 28: 209-216.

Quinn P.J., Carter M.E., Markey B.K. and Carter G.R. 1998. Clinical veterinary microbiology (2nd Edn). Mosby, London. Pp. 137-143, 254-258.
Raji, M.A., Adogva, A.T., Natala, A.J., and Oladele, S.B. 2000. The prevalence and gross pathological lesions of ovine and caprine pneumonia caused by bacterial agents in Zaria, Nigeria. Ghana J. Sci., 40: $3-4$

Ugochukwu, E. I. 1985. Isolation and identification of aerobic pathogenic bacteria from pneumonic lungs of goats suffering from pneumonia-enteritis complex. Bull. Anim. Health. Prod Afr., 33: 303-308.

World Health Organization. 2005. The World Health Report 2005: Make every mother and child count. World Health Organization.

Yesuf, M., Mazengia, H., and Chanie, M. 2012. Histopathological and Bacteriological Examination of Pneumonic Lungs of Small Ruminants Slaughtered at Gondar, Ethiopia. American-Eurasian J. Sci. Res., 7(6): 226-231.

\section{How to cite this article:}

Nishchal Dutta, Shafiqur Rahman, Ishfaq Maqbool and Najeeb ul Tarfain. 2018. Incidence of Microorganisms of Hygienic Interest in Organized and Unorganized Abattoirs of Jammu Region, India. Int.J.Curr.Microbiol.App.Sci. 7(12): 427-432. doi: https://doi.org/10.20546/ijcmas.2018.712.053 